\title{
Development of Nanocomposite Films with Durian Peel Nanocrystalline Cellulose
}

\author{
Zeinur R. F. Romadhon\& *I Gusti M. Sanjaya \\ Indonesia 60231 \\ Received 26 April 2021, Revised 14 June 2021, Accepted 10 November 2021 \\ doi: 10.22487/j24775185.2021.v10.i4.pp230-236
}

Chemistry Study Program/Faculty of Mathematics and Natural Sciences - Universitas Negeri Surabaya, Surabaya -

\begin{abstract}
This research aims to synthesize and characterize nanocomposite film with nanocrystalline cellulose (NCC) durian peel waste filler. Nanocomposite film was prepared by adding NCC with concentrations of $0 \%, 1 \%, 3 \%$, 5\%, and $7 \%$ to each mixture of chitosan and guar gum. Characterization of nanocomposite film includes tensile strength test, elongation test, water-resistance test, and biodegradability. Nanocomposite film with NCC 7\% showed a tensile strength value of $21.988 \mathrm{MPa}$; elongation of $10.3 \%$; and experienced degradability of $4.05 \mathrm{mg} /$ day, besides the characterization of the equal distribution of NCC in the chitosan-guar gum matrix was proven from the SEM results.
\end{abstract}

Keywords: NCC, nanocomposite film, durian peel

\section{Introduction}

Indonesia produces \pm 700 thousand tons of durian per year, around $79.48 \%$ is waste from a durian that is not utilized, such as peel and seeds (Nurrohmah et al., 2021; Yuniastuti et al., 2018). Durian peel waste processing has not been optimized as a helpful product. Until now, durian peel has only become waste in the landfill or trash on the roadside from people selling. In this study, the durian skin was extracted as NCC as a filler for nanocomposite film. It is done because the community's practical and flexible food packaging is usually made of plastic and increases the economic value of durian peel waste. In contrast, conventional plastics cannot be recycled and become waste. We need innovation in manufacturing films with biodegradable natural materials to overcome this. Durian peel can be used as NCC because it contains 50-60\% cellulose (Nurrohmah et al., 2021). The high cellulose content can make environmentally friendly films a transparent layer for food wrapping (Zhao et al., 2019).

NCC is a good material for the manufacture of nanocomposite polymers. Because its dimensions on the nanometre scale make NCC act as a composite (filler) in the polymer matrix, the surface will look smoother than centimeter-sized cellulose when used as a polymer filler; it isn't easy to mix with the matrix. Cellulose has advantages such as biodegradability, abundance, high strength, renewal, and several other superior properties (Wei et al., 2017). Reviewed from the properties of cellulose, NCC will be a good filler in polymers. NCC can be isolated from various cellulose sources, including plants, animals, bacteria \& algae. In principle, it can be extracted from almost all cellulosic materials using different procedures (Khalil et al., 2014).
NCC from durian skin waste will be used as a filler agent in chitosan-based nanocomposites film with plasticizers guar gum. Chitosan was chosen as a polymer because it has functional groups forming hydrogen bonds between chains. This bond can increase the mechanical properties of biopolymers (Afif et al., 2018). Also, as an edible coating, chitosan has good mechanical properties and is an excellent barrier to oxygen and aroma, also antimicrobial ((Abugoch et al., 2011; Natalia \& Muryeti, 2020; Natalia \& Muryeti, 2020). The water-soluble properties of guar gum are widely used as a gradient incorporated in bio-nano composites for food packaging applications (Lubambo et al., 2013; Rao et al., 2010). Guar gum acts as a plasticizer in biopolymers because it is hydrophilic (Govin et al., 2017). This paper aims to present a route to produce an environmentally friendly product.

\section{Method}

The tools used in this research are magnetic stirrer, analytical scale, oven, centrifuge, ultrasonic bath, 100 mesh sieve, blender, Universal pH indicator, electric stove, and glassware. The materials used are durian peel on the white part as raw material for NCC preparation, $\mathrm{NaOH} 10 \%$, $\mathrm{H}_{2} \mathrm{O}_{2} 10 \%, \mathrm{H}_{2} \mathrm{SO}_{4} 45 \%$, chitosan, guar gum, glacial acetic acid, distilled water.

\section{Preparation of nanocrystalline cellulose (NCC)}

Extraction of cellulose from durian skins was done by cutting the white part of the durian skin into dice and then drying it in an oven at $100{ }^{\circ} \mathrm{C}$ for 2 hours. After drying, it was mashed to a powder and filtered with a 100 mesh sieve. The durian skin powder was then immersed in $\mathrm{NaOH} 10 \%(\mathrm{~b} / \mathrm{v})$ with a ratio of powder and $\mathrm{NaOH}$ of $1: 10$, then stirred until all the powder was immersed in $\mathrm{NaOH}$, 
soaked for 24 hours. The bleaching process was carried out using $\mathrm{H}_{2} \mathrm{O}_{2} \quad 10 \%(\mathrm{v} / \mathrm{v})$; the powder was soaked in $\mathrm{H}_{2} \mathrm{O}_{2}$ for 24 hours, then the powder was washed with distilled water that has been boiled. The results of the cellulose extraction were passed to a pH 7. After that, it was dried in an oven at $40{ }^{\circ} \mathrm{C}$. Furthermore, acid hydrolysis was carried out by adding $250 \mathrm{~mL} \mathrm{H}_{2} \mathrm{SO}_{4} 45 \%$ at $55{ }^{\circ} \mathrm{C}$ for 30 minutes, then stirring vigorously. The hydrolysis reaction was stopped after 30 minutes. Then the sample was centrifuged to form a suspension. The sample was washed until it was neutral using a centrifuge at a speed of $12000 \mathrm{rpm}$ for 5 minutes. The suspended NCC were dialyzed for 72 hours. NCC, which was already in the form of a colloid suspension, was then ultrasonicated for 10 minutes in an ice bath, then carried out freeze-drying.

\section{Making nanocomposite film}

Chitosan powder in size 80 mesh was dissolved in glacial acetic acid with a concentration of $2.5 \%$, then mixed using a magnetic stirrer for 4 hours to form a chitosan solution ( $1 \% \mathrm{w} / \mathrm{v})$. Furthermore, guar gum powder was dissolved in distilled water using a water bath of $90{ }^{\circ} \mathrm{C}$ for 5 minutes. A good mixture of plastic biodegradable uses $85 \mathrm{~mL}$ of chitosan solution and $15 \mathrm{~mL}$ of guar gum solution, then mixed using a magnetic stirrer at $60{ }^{\circ} \mathrm{C}$ for 1 hour. The chitosan-guar gum solution was mixed with NCC that has been made with variations of $0 \%$ (without NCC), $1 \%, 3 \%, 5 \%, \& 7 \%$ (this variation was taken based on the dry weight of chitosan and guar gum) mixed using a magnetic stirrer for 20 minutes. Furthermore, the mixture of the three ingredients was added to a baking sheet and then oven at $50{ }^{\circ} \mathrm{C}$ for 4 hours.

\section{Result and Discussion}

NCC, made from durian peel cellulose, is physically white, gel-shaped, and has no aroma (Figure 1). NCC extraction with acid hydrolysis method $\left(\mathrm{H}_{2} \mathrm{SO}_{4}\right)$ resulted in a yield of $92.46 \%$, which was obtained from 38.745 grams of cellulose

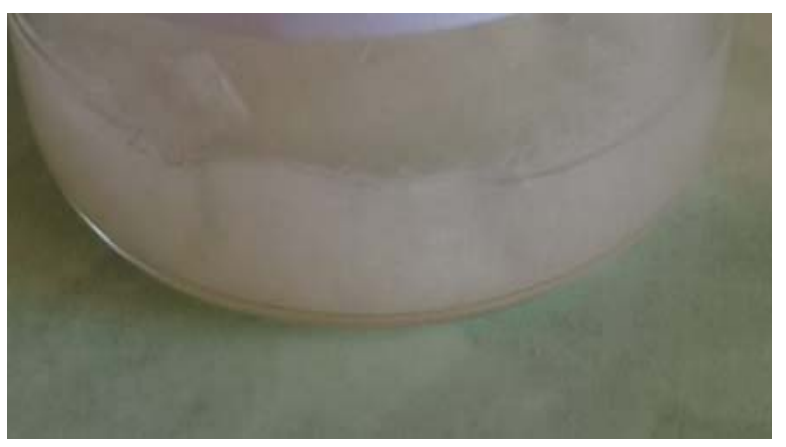

Figure 1. NCC durian peel waste

The FTIR test results of the NCC durian skin are shown in the image below (Figure 2). The absorption area of about $3400 \mathrm{~cm}^{-1}$ is the intermolecular and intramolecular $\mathrm{O}-\mathrm{H}$ stretch bonds (Hamid et al., 2016; Khan et al., 2012). The absorption peak of around 2800-3000 $\mathrm{cm}^{-1}$ was identified as alkaline $\mathrm{CH}$ associated with the $\mathrm{CH}_{2}$ group of cellulose (Zik et al., 2020). In principle, at an absorption value of about $1600 \mathrm{~cm}^{-1}$, it is related to the stretching of the $\mathrm{H}-\mathrm{O}-\mathrm{H}$ bonds from water molecules absorbed in carbohydrates (Hartati et al., 2019). A small peak of about $1424 \mathrm{~cm}^{-1}$ is associated with an intermolecular hydrogen bond in the $\mathrm{C}_{6}$ group. A peak seen around $1300 \mathrm{~cm}^{-1}$ is related to asymmetrical C-H and $\mathrm{C}-\mathrm{O}$ bonds in the aromatic ring of polysaccharides ((Haafiz et al., 2014; Zhokh \& Strizhak, 2018; Zhokh $\&$ Strizhak, 2018). The absorption peak around 1027$896 \mathrm{~cm}^{-1}$ is formed from the vibration of the C-O-C bond, which is considered a typical cellulose bond
(Celebi \& Kurt, 2015). The visible peak of around $1159 \mathrm{~cm}^{-1}$ indicates glycosidic bonds in the cellulose chain (Putri \& Gea, 2018). Changes in the bonds in cellulose converted into NCC occur due to the hydrolysis of sulfuric acid in the amorphous (Effendi et al., 2015; Siqueira et al., 2010). During the acid hydrolysis process, the undeveloped part of the cellulose is dissolved, resulting in crystalline in the form of nanoparticles.

The NCC was analyzed using PSA (Particle Size Analysis) to determine the particle size. The principle of measuring with the PSA tool is based on laser scattering by the particles in the sample (Nuraeni et al., 2013). The average size of the NCC diameter based on the test results is $14.36 \mathrm{~nm}$ (Figure 3). By (Khalil et al., 2014; George et al., 2011) NCC, is also known as nanowhiskers. It has a relatively low aspect ratio of 2$20 \mathrm{~nm}$ in diameter and 100-600 nm in length. 


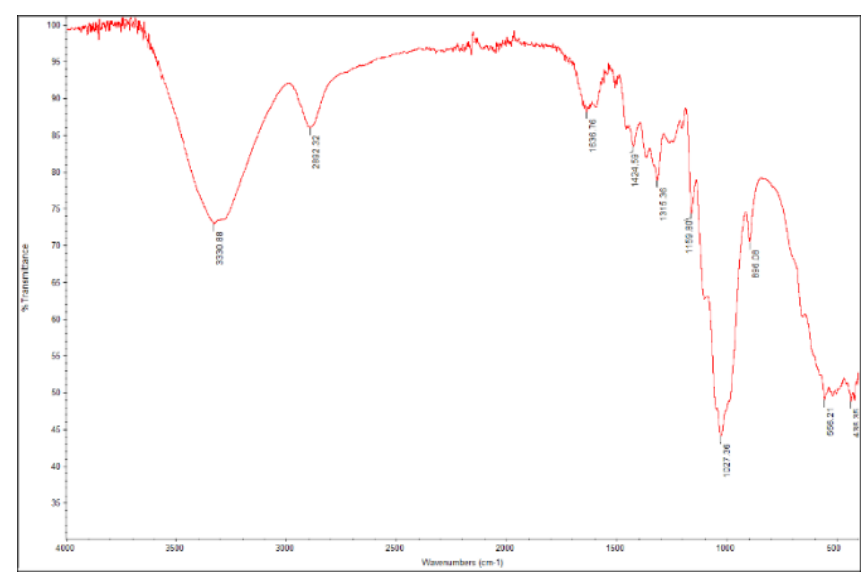

Figure 2. Result of FTIR NCC test

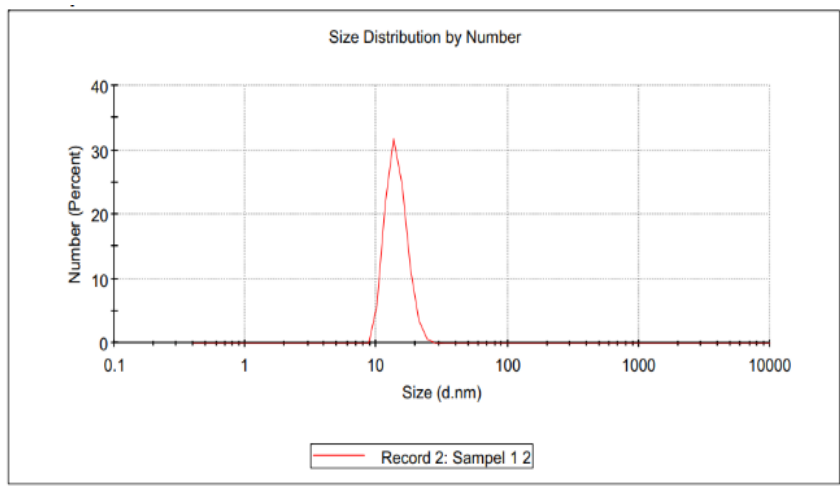

Figure 3. Result of PSA NCC test

The nanocomposite film made from chitosanguar gum-NCC was physically transparent and slightly yellowish (Figure 4). The nanocomposite film was tested mechanically using tensile strength, elongation, water resistance, and biodegradability.

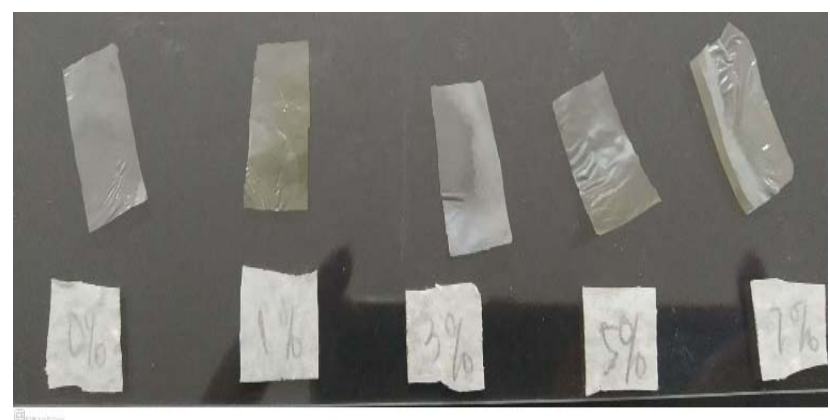

Figure 4. Nanocomposite film chitosan-guar gum-NCC

The films' tensile strength test results (Figure 5) gave the best results in the variation of the addition NCC 7\%, $21.988 \mathrm{MPa}$. The increase in tensile strength in the nanocomposite film made from chitosan-guar gum reinforced with NCC is associated with the effective tension transfer between the nanocrystals and the polymer surface. The interaction occurs between the anion of the NCC sulfate group and the cation of the chitosan amine group, which encourages the bond between the two polymers, thereby increasing the tensile strength of nanocomposites film (de Mesquita et al., 2010). 
According to Ureña-Benavides et al. (2010), the mechanical strength of alginate nanocomposite fibers can be increased by incorporating NCC. comparing the length addition that occurs with the size of the material before the tensile test is carried out (Arini et al., 2017). The amount of chitosan may cause a decrease in the bond distance between molecules. It

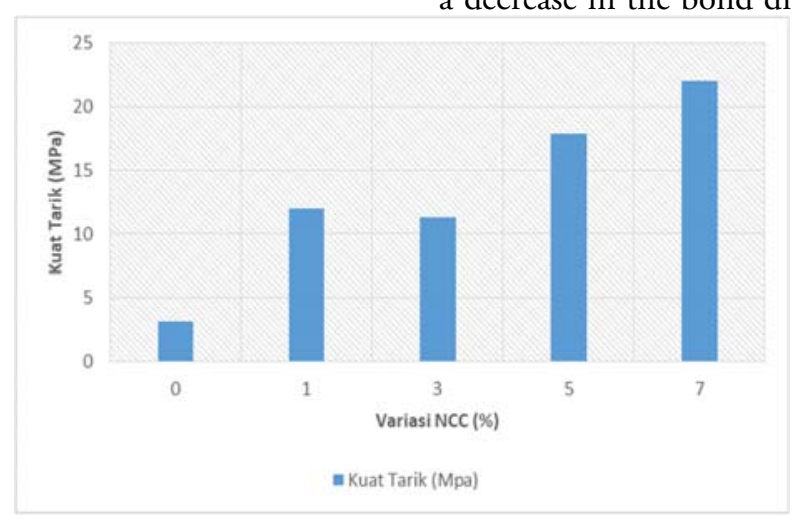

Figure 5. Result of tensile strength test for nanocomposite film.

The following mechanical test is elongation, which is the change in the maximum length of the film before breaking. The elongation test is carried out by makes the results of the elongation test (Figure 6) are not in accordance (Ginting et al., 2016).

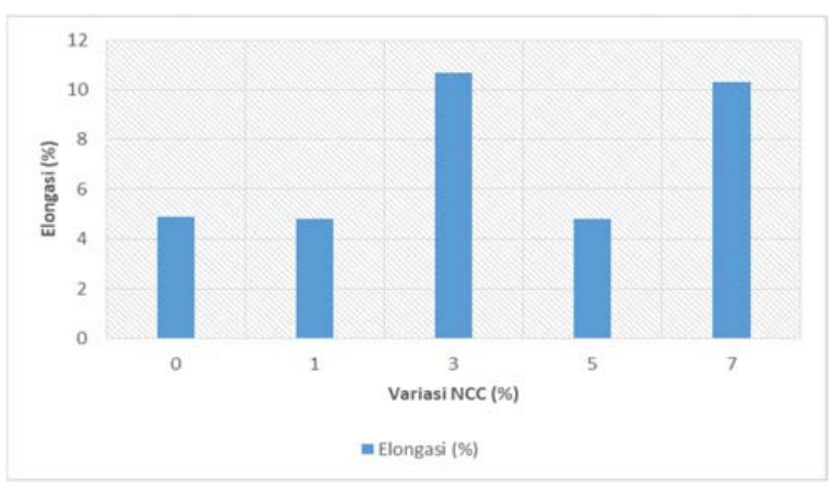

Figure 6. Result of nanocomposite film elongation test.

The water resistance test is a test carried out to determine how much absorption of the film is against water. The components of the film influence these properties. The water resistance test is carried out to assess the regularity of the bonds in the polymer, which is determined through the percentage of polymer weight gain after inflating (Illing \& MB, 2017). The resulting film (Figure 7) has low water resistance. The higher the percentage of polymer weight gain, the lower the water resistance of the film. The primary material of nanocomposites film is chitosan which contains a hydroxyl group ( $\mathrm{OH}$ group) that is hydrophilic. This hydroxyl group encourages water uptake in bioplastics to be higher (Afif et al., 2018).

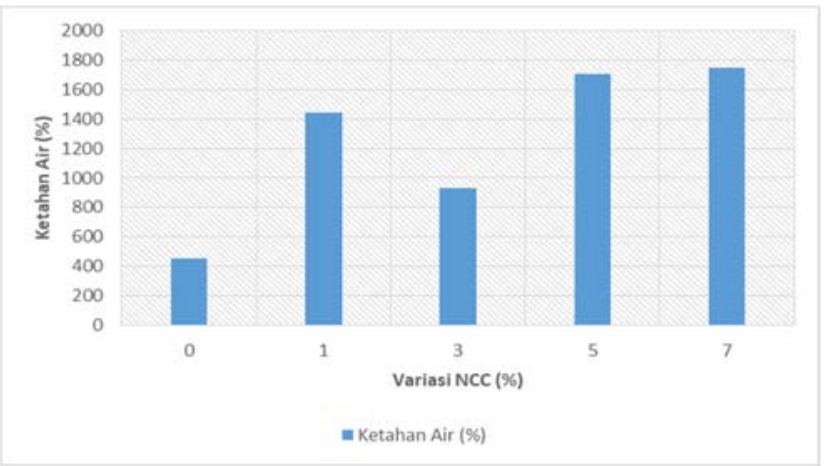

Figure 7. Result of nanocomposite film water resistance test. 
The biodegradability test was carried out to determine the degradability of nanocomposite films made in the soil. This test is carried out using the Soil Burial Test by burying the film in the semi-wet ground using a tin can with a depth of $5-10 \mathrm{~cm}$, then observing the weight of the film after and before burial
(Anggarini, 2013). The best biodegradability results (Figure 8) are $4.05 \mathrm{mg} /$ day on a variety NCC $7 \%$. All the raw materials of the films made from nature can be renewed and readily biodegradable because it is nontoxic and easily degraded biologically.

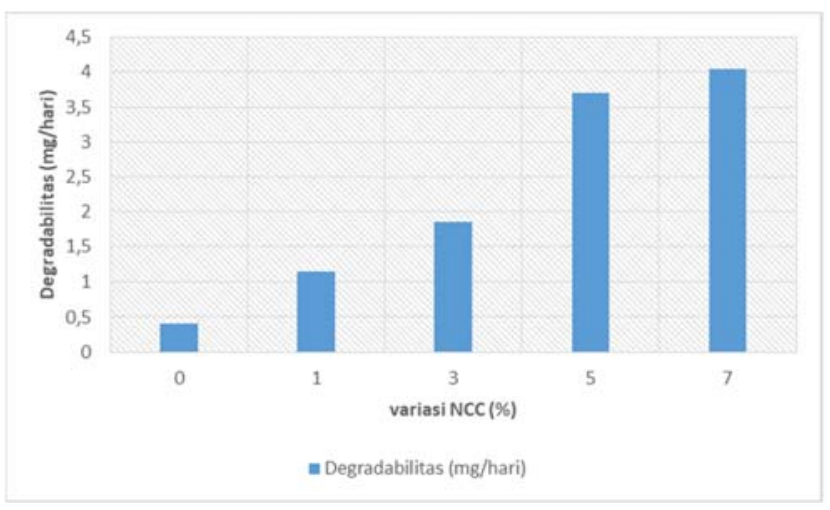

Figure 8. Result of nanocomposite film degradability test

After being tested mechanically, the film nanocomposite obtained the best film results in the addition of NCC $7 \%$. Furthermore, the variation of NCC 7\% was carried out by SEM and FTIR tests to determine whether or not NCC had been added. The FTIR spectrum results of the chitosan-guar gum nanocomposite film with NCC 7\%, guar gum, chitosan, and NCC are shown in the image below (Figure 9).

The FTIR spectrum results of the nanocomposite film that has been added with NCC have peaked around $3600-3000 \mathrm{~cm}^{-1}$ with a maximum peak at 3283 $\mathrm{cm}^{-1}$. It indicates a vigorous absorption intensity of NCC caused by the hydrogen bonding between chitosan and NCC (Khan et al., 2010). Meanwhile, according to previous studies, the peak intensity at
$1071 \mathrm{~cm}^{-1}$ and $1020 \mathrm{~cm}^{-1}$ increased due to the added NCC (Tang et al., 2018). FTIR test results showed the addition of NCC caused an increase in hydrogen bonding in polymer-based nanocomposites, which might increase the mechanical properties of the nanocomposite film of the chitosan-guar gum produced.

In SEM (Scanning Electron Microscopy), images are made based on the detection of new electrons (secondary electrons) or reflected electrons that emerge from the surface of the sample when the surface of the sample is scanned with an electron beam (Sujatno et al., 2017). The results of the SEM test with 10000x magnification showed the level of NCC dispersion in the chitosan-guar gum matrix as a nanocomposite.

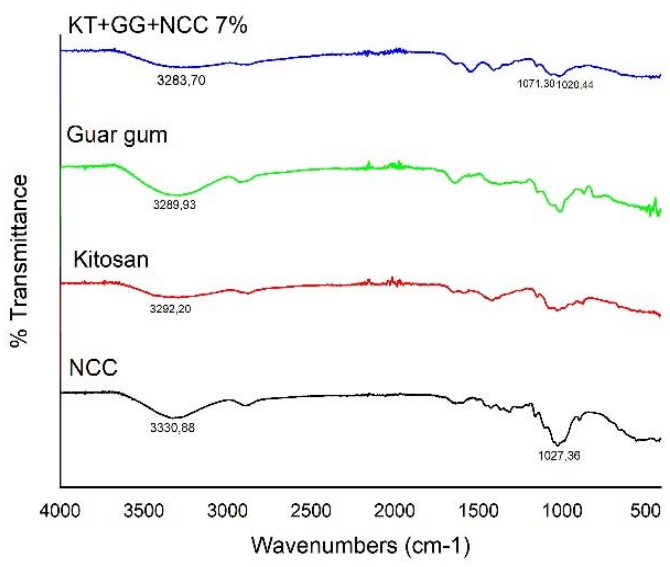

Figure 9. Result of FTIR test NCC, chitosan, guar gum, chitosan+guar gum+NCC 7\% 
The addition of NCC causes the surface of the film to become uneven, NCC appears as a light lump on the chitosan-guar gum nanocomposite film, shown in the image below (Figure 10), the results obtained are by previous studies (Tang et al., 2018) that the addition of NCC causes changes in film morphology, the surface of the film becomes uneven. It appears as a light lump in the composite film.

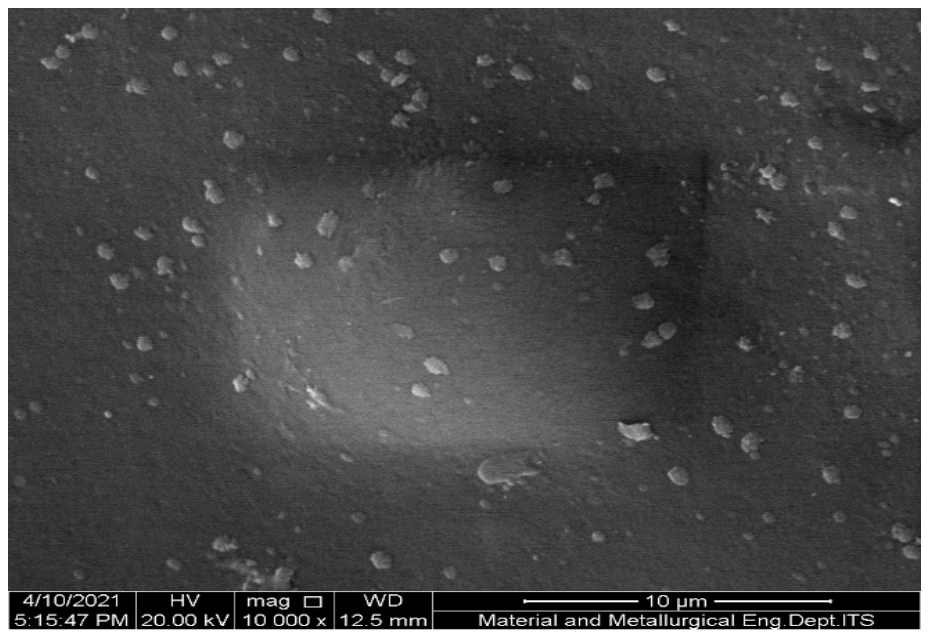

Figure 10. Result of SEM test for nanocomposite film with 10000× magnification.

\section{Conclusions}

Biodegradable chitosan-guar gum-NCC nanocomposites film was prepared with various additions of NCC. The effect of NCC addition on the overall mechanical properties of the nanocomposites film obtained increased, especially in nanocomposites with film NCC 7\%. Nanocomposite film with NCC $7 \%$ showed a tensile strength value of $21.988 \mathrm{MP}$; elongation of $10.3 \%$; and experienced degradability of $4.05 \mathrm{mg} /$ day, besides the characterization of the equal distribution of NCC in the chitosan-guar gum matrix was proven from the SEM results.

\section{Acknowledgments}

The author would like to thank God Almighty for his blessings and grace. This research can run smoothly, the chemistry laboratory assistants of FMIPA UNESA, and all parties who have helped implement the study.

\section{References}

Khalil, H. P. S. A., Davoudpour, Y., Aprilia, N. A. S., Mustapha, A., Islam, Md. N., \& Dungani, R. (2014). Nanocellulose-based polymer nanocomposite: Isolation, characterization, and applications. In V. K. Thakur (Ed.), Nanocellulose Polymer Nanocomposites: Fundamentals and Applications (pp. 273-309). Washington: Wiley Blackwell.

Afif, M., Wijayati, N., \& Mursiti, S. (2018). Pembuatan dan karakterisasi bioplastik dari pati biji alpukat-kitosan dengan plasticizer sorbitol. Indonesian Journal of Chemical Science, 7(2), 102109.

Anggarini, F. (2013). Aplikasi plasticizer gliserol pada pembuatan plastik biodegradable dari biji nangka.
Unpublished Undergraduate Thesis. Semarang: Universitas Negeri Semarang.

Arini, D., Ulum, M. S., \& Kasman. (2017). Pembuatan dan pengujian sifat mekanik plastik biodegradable berbasis tepung biji durian. Natural Science: Journal of Science and Technology, 6(3), 276-283.

Celebi, H., \& Kurt, A. (2015). Effects of processing on the properties of chitosan/cellulose nanocrystal films. Carbohydrate Polymers, 133(November), 284-293.

Abugoch, L. E., Tapia, C., Villamán, M. C., YazdaniPedram, M., \& Díaz-Dosque, M. (2011). Characterization of quinoa protein-chitosan blend edible films. Food Hydrocolloids, 25(5), 879886.

Effendi, D. B., Rosyid, N. H., Nandiyanto, A. B. D., \& Mudzakir, A. (2015). Review: Sintesis Nanoselulosa. Jurnal Integrasi Proses, 5(2), 61-74.

George, J., Ramana, K. V., Bawa, A. S., \& Siddaramaiah. (2011). Bacterial cellulose nanocrystals exhibiting high thermal stability and their polymer nanocomposites. International Journal of Biological Macromolecules, 48(1), 50-57.

Ginting, M. H. S., Kristiani, M., Amelia, Y., \& Hasibuan, R. (2016). The effect of chitosan , sorbitol, and heating temperature bioplastic solution on mechanical properties of bioplastic from durian seed starch (durio zibehinus). International Journal of Engineering Research and Applications, 6(1), 33-38.

Govin, A., Schmidt, W., Bartholin, M.-C., \& Grosseau, P. (2017). Combination of guar gum derivatives and superplasticizers, impact on properties of Portland cement-pastes. Concrete 2017 - Advances in Concrete Materials and 
Structures and 3rd International Congress on Durability of Concrete (pp. 1-10). Adélaïde, Australia.

Haafiz, M. K. M., Hassan, A., Zakaria, Z., \& Inuwa, I. M. (2014). Isolation and characterization of cellulose nanowhiskers from oil palm biomass microcrystalline cellulose. Carbohydrate Polymers, 103(March), 119-125.

Hamid, S. B. A., Chowdhury, Z. Z., Karim, Md. Z., \& Ali, Md. E. (2016). Catalytic isolation and physicochemical properties of nanocrystalline cellulose (NCC) using $\mathrm{HCl}-\mathrm{FeCl} 3$ system combined with ultrasonication. BioResources, 11(2), 3840-3855.

Hartati, N., Kemala, T., Sutriah, K., \& Farobie, O. (2019). Kompatibilitas nanokristal selulosa termodifikasi setrimonium klorida (CTAC) dalam matriks poliasam laktat sebagai material pengemas. Jurnal Kimia Sains dan Aplikasi, 22(4), 157-163.

Illing, I., \& MB, S. (2017). Uji ketahanan air bioplastik dari limbah ampas sagu dengan penambahan variasi konsentrasi gelatin. Prosiding Seminar Nasional Universitas Cokroaminoto Palopo (pp. 182-189). Palopo: Universitas Cokroaminoto Palopo.

Khan, A., Khan, R. A., Salmieri, S., Tien, C. L., Riedl, B., Bouchard, J., Chauve, G., Tan, V., Kamal, M. R., \& Lacroix, M. (2012). Mechanical and barrier properties of nanocrystalline cellulose reinforced chitosan based nanocomposite films. Carbohydrate Polymers, 90(4), 1601-1608.

Khan, R. A., Salmieri, S., Dussault, D., UribeCalderon, J., Kamal, M. R., Safrany, A., \& Lacroix, M. (2010). Production and properties of nanocellulose-reinforced methylcellulose-based biodegradable films. Journal of Agricultural and Food Chemistry, 58(13), 7878-7885.

Lubambo, A. F., de Freitas, R. A., Sierakowski, M-R., Lucyszyn, N., Sassaki, G. L., Serafim, B. M., \& Saul, C. K. (2013). Electrospinning of commercial guar-gum: Effects of purification and filtration. Carbohydrate Polymers, 93(2), 484-491.

de Mesquita, J. P., Donnici, C. L., \& Pereira, F. V. (2010). Biobased nanocomposites from layer-bylayer assembly of cellulose nanowhiskers with chitosan. Biomacromolecules, 11(2), 473-480.

Natalia, E. V., \& Muryeti. (2020). Pembuatan plastik biodegradable dari pati singkong dan kitosan. Journal Printing and Packaging Technology, 1(1), 57-68.

Nuraeni, W., Daruwati, I., Maria, E., \& Sriyani, M. E. (2013). Verifikasi kinerja alat particle size analyzer (PSA) horiba Lb-550 untuk penentuan distribusi ukuran nanopartikel. Prosiding Seminar Nasional Sains Dan Teknologi Nuklir (pp. 266271). Bandung: Pusat Teknologi Nuklir Bahan dan Radiometri-BATAN.

Nurrohmah, K., Sari, A. K., Riziani, D., \& Kusumasari, S. (2021). MAKUDU (Makaroni kulit durian): Potensi pangan olahan praktis untuk mengurangi limbah kulit durian. Jurnal Ilmiah Teknologi dan Industri Pangan UNISRI, 6(1), 3040.

Putri, E., \& Gea, S. (2018). Isolasi dan karakterisasi nanokistral selulosa dari tandan sawit (elaeis guineensis jack). Elkawnie: Journal of Islamic Science and Technology, 4(1), 13-22.

Rao, M. S., Kanatt, S. R., Chawla, S. P., \& Sharma, A. (2010). Chitosan and guar gum composite films: Preparation, physical, mechanical and antimicrobial properties. Carbohydrate Polymers, 82(4), 1243-1247.

Siqueira, G., Bras, J., \& Dufresne, A. (2010). New process of chemical grafting of cellulose nanoparticles with a long chain isocyanate. Langmuir, 26(1), 402-411.

Sujatno, A., Salam, R., Bandriyana., \& Dimyati, A. (2017). Studi scanning electron microscopy (SEM) untuk karakterisasi proses oxidasi paduan zirkonium. Jurnal Forum Nuklir, 9(1), 44-50.

Tang, Y., Zhang, X., Zhao, R., Guo, D., \& Zhang, J. (2018). Preparation and properties of chitosan/guar gum/nanocrystalline cellulose nanocomposite films. Carbohydrate Polymers, 197(October), 128-136.

Ureña-Benavides, E. E., Brown, P. J., \& Kitchens, C. L. (2010). Effect of jet stretch and particle load on cellulose nanocrystal-alginate nanocomposite fibers. Langmuir, 26(17), 14263-14270.

Wei, L., Agarwal, U. P., Hirth, K. C., Matuana, L. M., Sabo, R. C., \& Stark, N. M. (2017). Chemical modification of nanocellulose with canola oil fatty acid methyl ester. Carbohydrate Polymers, 169(August), 108-116.

Yuniastuti, E., Anggita, A., Nandariyah, \& Sukaya. (2018). Local durian (Durio zibethinus murr.) exploration for potentially superior tree as parents in Ngrambe District, Ngawi. IOP Conference Series: Earth and Environmental Science (pp. 1-9). Orlando: IOP Publishing.

Zhao, G., Lyu, X., Lee, J., Cui, X., \& Chen, W. (2019). Biodegradable and transparent cellulose film prepared eco-friendly from durian rind for packaging application. Food Packaging and Shelf Life, 21(September), 1-6.

Zhokh, A., \& Strizhak, P. (2018). Thiele modulus having regard to the anomalous diffusion in a catalyst pellet. Chaos, Solitons and Fractals, 109(April), 58-63.

Zik, N. A. F. A., Sulaiman, S., \& Jamal, P. (2020). Biodiesel production from waste cooking oil using calcium oxide/nanocrystal cellulose/polyvinyl alcohol catalyst in a packed bed reactor. Renewable Energy, 155(August), 267-277. 